\title{
On the Two Salish Object Agreement Suffixes"
}

\author{
KAORU KIYOSAWA \\ Simon Fraser University
}

\section{Introduction}

Salish languages are famous for their rich morphological structures. They have a variety of affixes including lexical suffixes, transitive suffixes marking control and causation, and personal affixes. Among the personal affixes, some languages exhibit two sets of object suffixes. For example, Tillamook (Egesdal and Thompson 1998:250, 259) has two different forms for first-person singular object: $-c$ in (1a) and $-w \check{s}$ in (1b). ${ }^{1,2}$

$$
\begin{aligned}
& \text { a. c-wá-wi-c-Ø. } \\
& \text { ST-RDP-leave-TR:1SG.(S)OBJ-3SUB }{ }^{3} \\
& \text { 'They left me.' } \\
& \text { ART DSD-NM-RDP-kill-CS-1SG.(M)OBJ-3SUB } \\
& \text { 'They want to kill me.' }
\end{aligned}
$$

In contrast, Thompson $(1985: 397,394)$ has only one set of object suffixes, and thus $-\mathrm{cm}$ is the first-person singular object suffix in both (2a) and (2b).

\footnotetext{
* I would like to thank Donna Gerdts, Paul Kroeber, and Charles Ulrich for their comments and advice.

${ }^{1}$ Abbreviations for grammatical terms used in this paper are as follows. APPL applicative, ART article, ATN autonomous, AUX auxiliary, CONT continuative, CS causative, DAT dative, DET determiner, DIR directive, DSD desiderative, ERG ergative, FUT future, IMP imperative, NC noncontrol, NM nominalizer, NOM nominative, OBJ object, OBL oblique, PL plural, POSS possessor, PRT particle, PST past, RDP reduplication, SER serial, SG singular, ST stative, SUB subject, TR transitive.

${ }^{2}$ I have standardized hyphenations and glosses in the cited examples and regularized the orthography following Kroeber (1999). Any mistakes or misinterpretations are my own.

${ }^{3}$ The segmentation of the general transitive suffix and an S-object suffix can be problematic. In many languages, the general transitive suffix coalesces with the initial /s/ of the S-object resulting in $/ \mathrm{c} /$ or $/ \theta /$. See Table 2.
} 


\section{Kaoru Kiyosawa}

(2)

a. cú-n-cm-s.

say-TR-1SG.OBJ-3SUB

'He told me.'

b. $\mathrm{k}^{\mathrm{w}}$ ís-s-cm-s.

fall-CS-1SG.OBJ-3SUB

'She caused me to fall (or managed to make me fall).'

Previously in Kiyosawa (2004), I surveyed the distribution of two sets of object suffixes, and showed that all Salish languages except Twana, Thompson, and Shuswap retain two sets of object suffixes, at least partially. I also proposed that form follows function in Salish object marking: there are two object sets formally because there are two different types of objects functionally. In this paper, I develop the functional discussion on the two object sets from Kiyosawa (2004), and add more evidence to support the hypothesis that the M-object set is equivalent to dative agreement.

\section{S-Objects and M-Objects}

The two sets of object suffixes are reconstructed by Newman (1980):

TABLE 1. Proto-Salish Object Pronominal Suffixes

\begin{tabular}{|l|c|c|c|c|c|}
\hline & $1 \mathrm{SG}$ & $2 \mathrm{SG}$ & $3 \mathrm{SG}$ & $1 \mathrm{PL}$ & $2 \mathrm{PL}$ \\
\hline Neutral Object & $*$-c $(<*$-t-s $)$ & $*_{\text {-ci }}(<*$-t-si $)$ & $* \varnothing$ & ${ }^{*}$-al & $*$-ulm \\
\hline Causative Object & $*$-mx & $*$-mi & $* \varnothing$ & $*_{\text {-mul }}$ & $*$-muł \\
\hline
\end{tabular}

They differ in distribution-one set typically follows the general transitive suffix and the other the causative suffix. Thus, one set has been referred to as "neutral" (Newman 1980) or "non-causative" (Kinkade 1982), and the other "causative" (Newman 1980, Kinkade 1982). Here I refer to them as S-OBJECT and M-OBJECT sets based on their form, following Kinkade (1998) and Montler (1996). Since third-person object suffixes are zero, I limit my discussion to firstand second-person object suffixes. Table 2 gives the two object suffixes for forms where there is a distinction. ${ }^{4}$

\footnotetext{
${ }^{4}$ As mentioned in footnote 5, the general transitive suffix coalesces with the initial $/ \mathrm{s} /$ of the $\mathrm{S}$ object resulting in $/ \mathrm{c} /$ or $/ \theta /$. The surface forms of the S-object set are shown in this paper where applicable. Also note that the initial /t/ of the plural S-objects is historically from the general transitive suffix in Bella Coola and Upper Chehalis (Paul Kroeber, p.c.). See Table 1 for Newman's (1980) reconstruction.
} 
TABLE 2. S-objects and M-objects ${ }^{5,6}$

\begin{tabular}{|c|c|c|c|c|c|c|}
\hline BRANCH & LG & OBJ & $1 \mathrm{SG}$ & $2 \mathrm{SG}$ & 1PL & $2 \mathrm{PL}$ \\
\hline \multirow{2}{*}{$\mathrm{Be}$} & \multirow{2}{*}{$\mathrm{Be}$} & $\mathrm{S}$ & $-c(a n)$ & & -tuł & \\
\hline & & $\mathrm{M}$ & $-\mathrm{m}(\mathrm{an}(\mathrm{ca}))$ & & -muk & \\
\hline \multirow{14}{*}{$\mathrm{CS}$} & \multirow{2}{*}{ S1 } & $\mathrm{S}$ & $-\theta$ & $-\theta \mathrm{i}$ & & \\
\hline & & M & $-\mathrm{ms}$ & $-\mathrm{mi}$ & & \\
\hline & \multirow{2}{*}{$\mathrm{Se}$} & $\mathrm{S}$ & $-c$ & -cí & & -ci...-élap \\
\hline & & $\mathrm{M}$ & $-\mathrm{mš}$ & $-\mathrm{mi}$ & & -mi...-élap \\
\hline & \multirow{2}{*}{$\mathrm{Sq}$} & $\mathrm{S}$ & $-\mathrm{c}$ & & & \\
\hline & & $\mathrm{M}$ & $-\mathrm{mš}$ & & & \\
\hline & \multirow{2}{*}{$\mathrm{Hl}$} & $\mathrm{S}$ & $-\theta a m s ̌ s$ & $-\theta$ amə & & \\
\hline & & M & -am̉šs & -amə & & \\
\hline & \multirow{2}{*}{$\mathrm{Sa}$} & $\mathrm{S}$ & $-s$ & -sə & & $-\mathrm{s} 2$ \\
\hline & & $\mathrm{M}$ & -ayəs & -ayə & & -ayə \\
\hline & \multirow{2}{*}{$\mathrm{Cl}$} & $\mathrm{S}$ & $-c$ & $-c$ & & $-\mathrm{c}$ \\
\hline & & M & -únəs & -únə & & -únə \\
\hline & \multirow{2}{*}{$\mathrm{Ld}$} & $\mathrm{S}$ & $-\mathrm{c}$ & -cid & & \\
\hline & & $\mathrm{M}$ & -bš & -bicid & & \\
\hline \multirow{2}{*}{ TS } & \multirow{2}{*}{$\mathrm{Ch}$} & $\mathrm{S}$ & $-c(a l)$ & -ci & $-\operatorname{tul}(\mathrm{l})$ & $-\operatorname{tul}(\uparrow)$ \\
\hline & & $\mathrm{M}$ & $-\mathrm{mš}(<-\mathrm{mal})$ & $-\mathrm{mi}$ & $-\operatorname{mul}(1)$ & $-\operatorname{mul}(1)$ \\
\hline \multirow{2}{*}{$\mathrm{Ti}$} & \multirow{2}{*}{$\mathrm{Ti}$} & $\mathrm{S}$ & $-\mathrm{c}$ & $-c \partial$ & & \\
\hline & & M & -wəš & -wว & & \\
\hline \multirow{2}{*}{ NIS } & \multirow{2}{*}{$\mathrm{Li}$} & $\mathrm{S}$ & $-\mathrm{c}(-\mathrm{al})$ & -ci(n)/-cih & & \\
\hline & & $\mathrm{M}$ & -tumx(-al) & -tumi(n)/-tumih & & \\
\hline \multirow{8}{*}{ SIS } & \multirow{2}{*}{ Ok } & $\mathrm{S}$ & & $-\mathrm{c}$ & & \\
\hline & & M & & $-(\mathrm{u}) \mathrm{m}$ & & \\
\hline & \multirow{2}{*}{$\mathrm{Sp}$} & $\mathrm{S}$ & & -cí & & \\
\hline & & M & & -(ú)m & & \\
\hline & \multirow{2}{*}{$\mathrm{Cr}$} & $\mathrm{S}$ & -ce(l) & -ci & & \\
\hline & & $\mathrm{M}$ & -me(l) & $-\mathrm{mi}$ & & \\
\hline & \multirow{2}{*}{$\mathrm{Cm}$} & $\mathrm{S}$ & $-c(a(1))$ & $-\mathrm{ci}$ & & \\
\hline & & M & $-\mathrm{m}$ & $-m$ & & \\
\hline
\end{tabular}

\footnotetext{
${ }^{5}$ Twana, Thompson, and Shuswap do not distinguish two sets of object suffixes. Therefore, they are excluded from Table 2.

${ }^{6}$ The key references that were consulted to ascertain the object suffix forms were: Bella Coola (Davis and Saunders 1997), Clallam (Montler 1996), Coeur d'Alene (Doak 1997), Columbian (Kinkade 1980, 1982), Halkomelem (Gerdts 1988), Lillooet (Van Eijk 1997), Lushootseed (Bates et al. 1994, Hess 1967, Hess and Bates 1998), Okanagan (A. Mattina 1973, 1994; N. Mattina 1993), Saanich (Montler 1986), Sechelt (Beaumont 1985), Shuswap (Kuipers 1974), Sliammon/Comox (Watanabe 1996, 2003), Kalispel/Spokane (Carlson 1972, 1980), Squamish (Kuipers 1967), Thompson (Thompson and Thompson 1992), Tillamook (Egesdal and Thompson 1998), Upper Chehalis (Kinkade 1991).
} 
The data are summarized in Table 3; the dots indicate where the distinction between S- and M-object sets is retained:

TABLE 3. S-object and M-object Retention

\begin{tabular}{|l|c|c|c|c|}
\hline \multicolumn{1}{|c|}{ LANGUAGE } & 1SG & 2SG & $1 \mathrm{PL}$ & 2PL \\
\hline $\mathrm{Ch}$ & $\bullet$ & $\bullet$ & $\bullet$ & $\bullet$ \\
\hline $\mathrm{Cl}, \mathrm{Sa}, \mathrm{Se}$ & $\bullet$ & $\bullet$ & & $\bullet$ \\
\hline $\mathrm{Be}$ & $\bullet$ & & $\bullet$ & \\
\hline $\mathrm{Cm}, \mathrm{Cr}, \mathrm{Hl}, \mathrm{Ld}, \mathrm{Li}, \mathrm{Sl}, \mathrm{Ti}$ & $\bullet$ & $\bullet$ & & \\
\hline $\mathrm{Sq}$ & $\bullet$ & & & \\
\hline $\mathrm{Ok}, \mathrm{Sp}$ & & $\bullet$ & & \\
\hline
\end{tabular}

Upper Chehalis is the only language that retains two full paradigms of suffixes. Other languages have leveled the paradigm mostly in the plural. Interior Salish languages have lost it in both the first- and second-person plural object suffixes, and Central Salish languages have lost it in the first-person plural. Overall, no generalizations are possible about which languages have lost the distinction, either by branch or by person and number.

\section{The Distribution of Two Object Sets}

Salish languages form transitive constructions with various verbal suffixes. ${ }^{7}$ Those suffixes include the general transitive suffix, ${ }^{*}-n t$, and the causative suffix, $*_{-s t w}$. In addition, there is the non-control transitive suffix, *-nwá-n. The noncontrol transitive suffix *-nwá- $n$ is used for actions that are performed accidentally or accomplished with difficulty (Thompson 1985). I refer to these three suffixes collectively as "transitive suffixes." In addition, Salish languages have from two to six applicative suffixes, which often appear in combination with transitive suffixes. The distribution of the two object sets is summarized in Table 4:

TABLE 4. Distribution of Two Object Sets

\begin{tabular}{|c|c|}
\hline S-OBJECT & M-OBJECT \\
\hline General transitive & Causative, \\
& $\begin{array}{c}\text { Non-control, } \\
\text { Applicative *-nas }\end{array}$ \\
\hline
\end{tabular}

The important thing to note about *-nos is that it is not followed by any of the transitive suffixes, nor is any part of it transparently composed of a transitive suffix. Yet the applicative construction is syntactically transitive, and it is followed by M-object set. It appears in Central Salish languages (Clallam,

\footnotetext{
${ }^{7}$ The proto-forms of verbal suffixes are reconstructed by Kinkade (1998).
} 
Halkomelem, Lushootseed, Saanich, and Twana), Tsamosan (Upper Chehalis), and Tillamook, but it is not found in Interior Salish languages. The most frequent use of the relational applicative *-nas is with motion and speech act verbs. The applied object is usually the goal of a motion, as illustrated in (3), or the addressee of a speech act.

$$
\begin{array}{ll}
\text { H1 } & \text { Pi } \quad \text { yə-Pew̉ว-nəs-ám̉šš-əs. } \\
\text { AUX } & \text { SER-come-APPL-1SG.(M)OBJ-3ERG } \\
\text { 'He is coming toward/after me.' (Gerdts 1988:136) }
\end{array}
$$

Furthermore, Table 5 summarizes the distribution of the two object sets when following stacking of suffixes:

TABLE 5. Suffix Combinations

\begin{tabular}{|l|c|}
\hline SUFFIXES & OBJ \\
\hline Non-control + General transitive & $\mathrm{S}$ \\
\hline Applicative + General transitive & $\mathrm{S}$ \\
\hline Non-control + Causative & $\mathrm{M}$ \\
\hline Applicative + Causative & $\mathrm{M}$ \\
\hline Applicative + Non-control & $\mathrm{M}$ \\
\hline
\end{tabular}

The transitive suffixes play a key role in determining which object set occurs. The general transitive suffix governs the S-object set, and otherwise the M-object set occurs.

\subsection{The Case of $-x i(t)$}

We see from the above that there are two types of applicative suffixes- those that are followed by transitive suffixes and those that are not. In addition, there is one applicative suffix that seems to behave either way, depending on the language. This is the suffix *-xi, which is the most widespread of the redirective suffixes. As seen in Table 6, most languages have the S-object set with this suffix, but the Southern Interior Salish languages, with the exception of Coeur d'Alene, take the M-object set.

Therefore, we see that, in some Southern Interior Salish languages, -xit behaves like the applicative suffix *-nəs in taking M-object suffixes. This would be anomalous if the $t$ of -xit were regarded as the transitive suffix, since we know from the above discussion that $-t$ governs the S-object set. In fact, Kinkade (1982) does not separate $-x i$ and $-t$ in Columbian. So perhaps this suffix is now a single morpheme -xit in some languages. ${ }^{8}$ In other words, the applicative suffix and the

\footnotetext{
${ }^{8}$ A. Mattina (1985, 1994), N. Mattina (1996), and Van Eijk (1997) do not segment $-x($ i)t, while Doak (1997) and Carlson (1980) do.
} 
TABLE 6. *-xi with the Two Sets of Object Suffixes

\begin{tabular}{|c|c|c|c|c|}
\hline LG & DATA & OBJ & TRANSLATION & SOURCE \\
\hline $\mathrm{Sa}$ & X̌ət-sí-s-əs. & $\mathrm{S}$ & 'He got it ready for me.' & Montler 1986:171 \\
\hline $\mathrm{Cl}$ & k'wnə-sí-c-əク cn. ${ }^{9}$ & $\mathrm{~S}$ & 'I look at (s.t.) for you.' & Montler 1996:262 \\
\hline $\mathrm{Ld}$ & Púx̌ $\check{x}^{\mathrm{w}}-\mathrm{yi}-\mathrm{c}$ & $\mathrm{S}$ & $\begin{array}{l}\text { 'fetch it for me, go in } \\
\text { my place' }\end{array}$ & Hess 1967:43 \\
\hline $\mathrm{Ti}$ & (de) wał huq-tən-ší-c..$^{10}$ & $\mathrm{~S}$ & $\begin{array}{l}\text { 'He went after me with a } \\
\text { knife.' }\end{array}$ & $\begin{array}{l}\text { Egesdal \& Thompson } \\
\text { 1998:252 }\end{array}$ \\
\hline $\mathrm{Ch}$ & Pit yús-š-c. & $\mathrm{S}$ & 'He/she worked for me.' & Kinkade 1991:372 \\
\hline $\mathrm{Li}$ & n-kih-k-xí-c. & S & $\begin{array}{l}\text { 'Put it in your pack for } \\
\text { me!' }\end{array}$ & Van Eijk 1987:173 \\
\hline Ok & $\begin{array}{l}\text { //ka?kíc-xt-m-ən t } \\
\text { a-kł-q̉a?xán// }\end{array}$ & $\mathrm{M}$ & $\begin{array}{l}\text { 'I found you some } \\
\text { shoes.' }\end{array}$ & A. Mattina 1994:211 \\
\hline $\mathrm{Sp}$ & $\mathrm{k}^{\mathrm{w}} \mathrm{ú}^{\mathrm{l}}$-š-t-m-n. & M & 'I made you something.' & $\begin{array}{l}\text { Carlson \& Flett } \\
\text { 1989:35 }\end{array}$ \\
\hline $\mathrm{Cr}$ & mî̉-miî-š́í-c-n. & $\mathrm{S}$ & 'I told you a story.' & Doak 1997:151 \\
\hline $\mathrm{Cm}$ & káł-xt-m-s. & $\mathrm{M}$ & 'He/she gave it to me.' & Kinkade 1982:56 \\
\hline
\end{tabular}

general transitive suffix have been reanalyzed into a single morpheme. ${ }^{11}$ In this case, S-objects are not necessarily expected. In the next section, I propose a functional explanation for why the M-object set follows -xit.

Table 4 is modified as Table 7.

TABLE 7. Distribution of Two Object Sets

\begin{tabular}{|c|c|}
\hline S-OBJECT & M-OBJECT \\
\hline \multirow{3}{*}{ General transitive } & Causative, \\
& Non-control, \\
& Applicative *-nəs, ${ }^{*}$-xit (SIS) \\
\hline
\end{tabular}

This brings up the question: is there a common feature of causatives, non-control transitives, and applicatives that causes them to determine the M-object set? I turn to this question in the next section.

\footnotetext{
${ }^{9}$ Montler (1996:262) says, "The presence of the - $-\partial \eta$ is unexpected if this applicative included the basic transitivizer. Some speakers can, indeed, get forms such as $k^{\prime w}$ nasic $c n$ in more or less free variation with, but preferring, the $1 / 2$ form given..."

${ }^{10}$ In Tillamook, there is no independent evidence for segmenting/t/ from the applicative $-\check{s} i$, although the $/ t /$ in this suffix might have derived historically from a general transitive suffix (Paul Kroeber, p.c.).

${ }^{11}$ An alternative analysis is that -xit is the proto-form of this applicative suffix, and it was reanalyzed as two morphemes, -xi-t. However, such a reanalysis would have had to occur independently in other languages over several branches.
} 


\section{The Dative Hypothesis}

Salishanists generally refer to suffixes from both sets as "object" (or accusative, e.g., Barthmaier 2002, Doak 1997, Montler 1996). There is no doubt that both sets mark syntactic objects. However, since there are formally two different sets, it is worthwhile to explore the possibility that they may not be marking the same type of object. In this section, I propose that the M-object set registers agreement with a "dative" object. By this I mean either an indirect object or the sorts of direct objects that are often marked dative case rather than accusative case in dependentmarking languages.

First, as discussed above, the causee in the causative construction is an Mobject in all Salish languages. In many dependent-marking languages of the world, causees are often marked with dative case. For example, dative is used in the causative construction in Bolivian Quechua (Cole 1983):

$$
\begin{array}{lll}
\text { nuqa } & \text { wawa-man } & \text { yaca-či-n. } \\
\text { I } & \text { child-DAT } & \text { know-CS-1SG } \\
\text { 'I taught it to the child.' } &
\end{array}
$$

The object of the causative construction is often marked by a case other than accusative, since the causee is not a patient.

Second, objects of applicatives are also not patients. The applied object of *-nos is generally the goal of a motion verb or the goal (addressee) of a speech act verb. The applied object of -xit in Southern Interior Salish is a goal or benefactive. Cross-linguistically, we find that objects of these types are often marked dative in dependent-marking languages. For example, goals of motion, speech act verbs, and transfer verbs appear in the dative case in Japanese:

$$
\begin{aligned}
& \text { a. Bob-ga Canada-ni ki-ta. } \\
& \text { Bob-NOM Canada-DAT come-PST } \\
& \text { 'Bob came to Canada.' } \\
& \text { b. Bob-ga Mary-ni it-ta. } \\
& \text { Bob-NOM Mary-DAT say-PST } \\
& \text { 'Bob said to Mary.' } \\
& \text { c. Bob-ga Mary-ni hon-o age-ta. } \\
& \text { Bob-NOM Mary-DAT book-ACC give-PST } \\
& \text { 'Bob gave a book to Mary.' }
\end{aligned}
$$

Third, degrees of agency and control are often associated with case or agreement splits. Salish languages have overt transitive suffixes that distinguish control (6a) and non-control (6b): S-objects appear with the former and M-objects with the latter: 
(6)

\author{
Se a. ti i sép-et-c-as. \\ AUX slap-TR-1SG.(S)OBJ-3SUB \\ 'He/she slapped me.' (Beaumont 1985:122) \\ b. $\mathfrak{i}$ i sép̉-nú-mš-as. \\ AUX slap-NC:1SG.(M)OBJ-3SUB \\ 'He/she slapped me (accidentally).' (Beaumont 1985:122)
}

In some languages such as Eastern Pomo (McLendon 1978), high and low agency are differentially marked in the agreement system, and in Acehnese (Durie 1985), low agency transitives appear with neuter intransitive verbs. Also, in Japanese, causatives with high control have accusative-marked causees as in (7a), but ones with low control have dative causees as in (7b).

$$
\begin{array}{lll}
\text { a. Bob-ga } & \text { Mary-o } & \text { suwar-ase-ta. } \\
\text { Bob-NOM Mary-ACC } & \text { sit-CS-PST } \\
\text { 'Bob made Mary sit down.' } &
\end{array}
$$

b. Bob-ga Mary-ni suwar-ase-ta.

Bob-NOM Mary-DAT sit-CS-PST

'Bob let Mary sit down.'

Thus, the Salish M-object set as dative (6b) resonates with cross-linguistic observations concerning agency and control.

One more point to be made for Salish is that the four Southern Interior languages choose object sets on the basis of aspect. The Columbian data in (8a) is perfective and has the general transitive and an S-object, while (8b) is imperfective and has the causative suffix and an M-object. Other than aspect, there is no difference.

$$
\begin{aligned}
\mathrm{Cm} \quad \text { a. } & \text { yər-mí-n-c- } \varnothing . \\
& \text { push-APPL-TR-1SG.(S)OBJ-3 SUB } \\
& \text { 'He pushed me.' (Kinkade 1982:53) } \\
& \\
\text { b. } & \text { yər-mí-st-m-s. } \\
& \text { push-APPL-CS-1 SG.(M)OBJ-3SUB } \\
& \text { 'He is pushing me.' (Kinkade 1982:54) }
\end{aligned}
$$

This type of split marking based on aspect is quite familiar in split ergative systems. For example, in Kashmiri (Altaha 1985), dative case is used for the object in an imperfective as in (9b). 
On the Two Salish Object Agreement Suffixes

(9)
a. maštər-ən i:
i:s parnamiyt
mard- $\varnothing$.
teacher-ERG AUX.PL teach(PERF) men-NOM
'The teacher had taught the men.'
b. sahla- $\varnothing$ is hičnawa:n mard-an.
Sahla-NOM AUX.SG teaching men-DAT
'Sahla was teaching the men.'

In Hopper and Thompson (1980), punctuality is one of the parameters of transitivity: that is, punctual action is higher in transitivity than non-punctual action. In the Columbian examples in (8), it might be the case that the transitive suffix follows the function of the object suffix, that is, the imperfect construction is lower in transitivity, so M-objects are chosen. Then the general transitive suffix cannot precede the object suffix, so the causative suffix is used.

Given my hypothesis that the M-object set parallels dative case, its use for marking the non-patient objects of causative and applicative constructions is not unexpected. Also low agency/control and non-punctual aspect are associated with low transitivity. Cross-linguistically, low transitivity is often manifested as noncanonical case on the subject or the object (Haspelmath 2001). Thus, marking objects in non-control and imperfect environments with the object suffix set equivalent to dative case is not unexpected.

\section{Conclusion}

Salish languages, except Twana, Thompson, and Shuswap, distinguish two sets of suffixes for at least some first- and second-person object forms. These are referred to as S-objects and M-objects, based on their forms. As previously noted, the Sobject set follows the general transitive suffix, while the M-object set follows the causative suffix. In many Salish languages, the non-control and applicative suffixes are followed by a transitive suffix (either general transitive or causative), which in turn determines the object set. However, in other languages, an M-object is directly suffixed to the non-control transitive or applicative suffix. Thus, objects of the general transitive construction are S-objects, while objects of causatives, non-control transitives, and applicatives are M-objects.

The distribution of the two sets of object suffixes in the various transitive constructions suggests that the occurrence of the M-object set is functionally motivated. M-objects are used for objects that are not patients, e.g., the goal or benefactive objects of applicatives, or the causee in causative constructions. The functions of the M-object set are summarized in Table 8: 
TABLE 8. The Function of the M-object Set

\begin{tabular}{|l|c|c|c|c|}
\hline SEMANTIC FUNCTION OF OBJECT & \multicolumn{4}{|c|}{ SUFFIX } \\
\hline & $-n \partial s$ & $-x i t$ & CS & NC \\
\hline Goal & $\sqrt{ }$ & $\sqrt{ }$ & & \\
\hline Benefactive & & $\sqrt{ }$ & & \\
\hline Causee & & & $\sqrt{ }$ & \\
\hline Patient (in a low transitive clause) & & & $\sqrt{ }$ & $\sqrt{ }$ \\
\hline
\end{tabular}

Thus, the usage of the M-object set parallels the use of dative case on objects in dependent-marking languages.

Given that remnants of this system are seen in all branches of the family, two object sets should be posited for Proto-Salish. Furthermore, since there were two sets, they probably had distinct functions. In this paper, I have suggested that the function of the M-object set was to mark dative objects, and this role can still be observed in the use of M-objects in many Salish languages.

\section{References}

Altaha, Fayez. 1985. Non-nominative subjects in Kashmiri. Ph.D. diss., State University of New York at Buffalo.

Barthmaier, Paul. 2002. Transitivity and lexical suffixes in Okanagan. International Conference on Salish and Neighbouring Languages 37:1-15.

Bates, Dawn, Thom Hess, and Vi Hilbert. 1994. Lushootseed Dictionary. Seattle: University of Washington Press.

Beaumont, Ronald C. 1985. she shashishalhem, the Sechelt Language: Language, Stories and Sayings of the Sechelt Indian People of British Columbia. Penticton, B.C.: Theytus Books.

Carlson, Barry F. 1972. A Grammar of Spokane: A Salish Language of Eastern Washington. Ph.D. diss., University of Hawaii.

Carlson, Barry F. 1980. Two-goal transitive stems in Spokane Salish. International Journal of American Linguistics 46:21-26.

Carlson, Barry F., and Pauline Flett. 1989. Spokane Dictionary. University of Montana Occasional Papers in Linguistics 6.

Cole, Peter. 1983. The grammatical role of the causee in universal grammar. International Journal of American Linguistics 49:115-133.

Davis, Philip W., and Ross Saunders. 1997. A Grammar of Bella Coola. University of Montana Occasional Papers in Linguistics 13.

Doak, Ivy Grace. 1997. Coeur d'Alene grammatical relations. Ph.D. diss., University of Texas at Austin.

Durie, Mark. 1985. Control and decontrol in Acehnese. Australian Journal of Linguistics 5:43-53. 
Egesdal, Steven M., and M. Terry Thompson. 1998. A fresh look at Tillamook (Hutéyu) inflectional morphology. In E. Czaykowska-Higgins and M. D. Kinkade, eds., Salish Languages and Linguistics: Theoretical and Descriptive Perspectives, 235-273. Berlin: Mouton de Gruyter.

Gerdts, Donna B. 1988. Object and Absolutive in Halkomelem Salish. New York: Garland.

Haspelmath, Martin. 2001. Non-canonical marking of core arguments in European languages. In A. Y. Aikhenvald, R. M. W. Dixon, and M. Onishi, eds., Non-Canonical Marking of Subjects and Objects, 53-84. Amsterdam: John Benjamins.

Hess, Thomas M. 1967. Snohomish grammatical structure. Ph.D. diss., University of Washington.

Hess, Thomas M., and Dawn Bates. 1998. Semantic role assignment in Lushootseed causatives. International Conference on Salish and Neighbouring Languages 33:221-234.

Hopper, Paul J., and Sandra A. Thompson. 1980. Transitivity in grammar and discourse. Language 56:251-299.

Kinkade, M. Dale. 1980. Columbian Salish -xí, -t, -tút. International Journal of American Linguistics 46:33-36.

Kinkade, M. Dale. 1982. Transitive inflection in Moses-Columbian Salish. Kansas Working Paper in Linguistics 7:49-62.

Kinkade, M. Dale. 1991. Upper Chehalis Dictionary. University of Montana Occasional Papers in Linguistics 7.

Kinkade, M. Dale. 1998. Comparative Salish seminar. Ms., University of British Columbia.

Kiyosawa, Kaoru. 2004. The form and function of the two Salish object suffix sets. In D. B. Gerdts and L. Matthewson, eds., Studies in Salish Linguistics in Honor of M. Dale Kinkade, 235-256. University of Montana Occasional Papers in Linguistics 17.

Kroeber, Paul D. 1999. The Salish Language Family: Reconstructing Syntax. Lincoln: The University of Nebraska Press.

Kuipers, Aert H. 1967. The Squamish Language: Grammar, Texts, Dictionary. The Hague: Mouton.

Kuipers, Aert H. 1974. The Shuswap Language: Grammar, Texts, Dictionary. The Hague: Mouton.

Mattina, Anthony. 1973. Colville grammatical structure. Ph.D. diss., University of Hawaii.

Mattina, Anthony. 1985. The Golden Woman: The Colville Narrative of Peter J. Seymour. Tucson: The University of Arizona Press.

Mattina, Anthony. 1994. -tult, and more on Okanagan transitive forms: A working paper. International Conference on Salish and Neighbouring Languages 29:204-231. 
Mattina, Nancy. 1993. Some lexical properties of Colville-Okanagan ditransitives. International Conference on Salish and Neighbouring Languages 28:265284.

Mattina, Nancy J. 1996. Aspect and category in Okanagan word formation. Ph.D. diss., Simon Fraser University.

McLendon, Sally. 1978. Ergativity, case, and transitivity in Eastern Pomo. International Journal of American Linguistics 44:1-9.

Montler, Timothy R. 1986. An Outline of the Morphology and Phonology of Saanich, North Straits Salish. University of Montana Occasional Papers in Linguistics 4.

Montler, Timothy R. 1996. Some Klallam paradigms. International Conference on Salish and Neighbouring Languages 31:257-263.

Newman, Stanley. 1980. Functional changes in the Salish pronominal system. International Journal of American Linguistics 46:155-167.

Thompson, Laurence C. 1985. Control in Salish grammar. In F. Plank, ed., Relational Typology, 391-428. Berlin: Mouton de Gruyter.

Thompson, Laurence C., and M. Terry Thompson. 1992. The Thompson Language. University of Montana Occasional Papers in Linguistics 8.

Van Eijk, Jan P. 1987. Dictionary of the Lillooet language. Ms., University of Victoria.

Van Eijk, Jan P. 1997. The Lillooet Language: Phonology, Morphology, Syntax. Vancouver: UBC Press.

Watanabe, Honoré. 1996. Sliammon (Mainland Comox) transitive constructions with -Pzm, -ni, and -mi. International Conference on Salish and Neighbouring Languages 31:327-338.

Watanabe, Honoré. 2003. A Morphological Description of Sliammon, Mainland Comox Salish, with a Sketch of Syntax. Osaka: Faculty of Informatics, Osaka Gakuin University.

Linguistics Department

Simon Fraser University

Burnaby, B.C. V5A 1S6

Canada

kkiyosaw@sfu.ca 